\title{
Safety of Some Synthetic Food Colours: Review
}

\author{
Abdalla S.M. Ammar, ${ }^{1, a,}$, Mennat-Allah I. Atwa ${ }^{1, b}$, Dorreya M. Faress ${ }^{1, c}$, Ashgan M. Ali ${ }^{1, d}$ \\ ${ }^{l}$ Department of Food Science, Faculty of Agriculture, Cairo University, Egypt \\ ${ }^{*}$ Corresponding author
}

A R T I C L E IN F O A B S T R A C T

Review Article

Received : 02/04/2021

Accepted : 11/08/2021

Food additives are used to protect food, increase quality and extend shelf life in many stages, from production to consumption of food. Colorants added by food producers to color food or to adjust the color to desired level are among the commonly used food additives. Considering today's developing production technologies, foods fade or discolor at various stages of processing, storage, and sale due to physical and chemical conditions such as heat, light, $\mathrm{pH}$ and oxygen. Colorants are used to regain these color losses, to enhance weak colors, to give color to the food that is actually colorless, and to win back the favour of customers by hiding low quality. Therefore, the most used food colorants in Canada, China, European Union, Mexico and United States of America were presented. The chemical name, chemical structure, common uses, acceptable daily intake (ADI),

Keywords: and toxicity literature of six most used artificial food colors were reviewed.

Food

Processing

Artificial

Safety

Additives

\section{Introduction}

Food colour considered as an additive and according to the regulation definition, "it is any dye, pigment, or other substance that can impart colour to a food, drug, or cosmetic or to the human body." (FDA,2018). Addition of colorants to foods is thought to have occurred in Egyptian cities, where candy makers around $1500 \mathrm{BC}$ added natural extracts and wine to improve the products appearance (Meggos, 1995). In 1856 the first synthetic colour (mauvine), was developed by Sir William Henry Perkin and the first chemically synthesized colorants were created from aniline in 1900s (Maronpot et al., 2020). Colour is an important characteristic and selection criterion for food choice. Recent studies have highlighted this importance and have shown how selection may change among certain populations, and over time (Clydesdale, 1993). Colorants are used in the production of soft drinks, candies, chewing gums, chocolates, jelly, bakery products, canned and vegetable products, dairy products, and meat and fish products (Asif Ahmed et al., 2021). There was no control over this use of colour and so inevitably legislation came into force. In particular that was as a result of health concerns over some of the toxic compounds used. An established list of permitted synthetic colours eventually came into force in most countries early in this century. In the last twenty years however, consumers have become increasingly aware of the ingredients in their foods and as such they require foods to be as 'natural' as possible. This combined with technological developments has fuelled the increase in the usage of naturally derived colours. Naturally derived colours are usually less stable to heat, light, $\mathrm{pH}$ and oxygen. Stability of natural pigments is considered the main challenge to overcome for their utilization as food colorants (Jadhav and Bhujbal, 2020). They may interact with other ingredients, resulting in the development of unwanted colours and flavours and all hues might not be available. Therefore, this article reviews the scope of some synthetic colours in food processing and increasing the awareness of safety limits of food colorants. 


\section{Synthetic Food Colours Impacts}

Some of food colours and additives were declassified as human carcinogens following the comprehensive evaluation of results of at least three tests; cytotoxicity, genotoxicity and mutagenicity in vitro and some in vivo to guarantee safety of these colours. (Thomas and Adegoke, 2015).

The objectives of genotoxicity tests are to detect mutagens and carcinogens (Sasaki et al., 2000). The tests are designed and aimed at detecting compounds that induce genetic damage by various mechanisms.

\section{The Most Used Synthetic Food Colours}

The most used food colorants in Canada, China, European Union, Mexico and United States of America are presented in Table 1.

\section{Synthetic Colours Safety Literature}

The following tables (Tables 2-7) represent the chemical name, chemical structure, common uses, ADI, and toxicity literature commentary of six most used artificial food colours.

\section{Amaranth}

A dark reddish powder is soluble in water and slightly soluble in ethanol. The color intensity of the solution cannot be changed by hydrochloric acid while, sodium hydroxide increases it. Table (2) shows the chemical name, chemical structure, common uses and ADI of Amaranth.

Gene mutation

There are many reports documenting the lack of genotoxicity of Amaranth on bacteria (Brown et al., 1978; Haveland-Smith and Combes, 1980; Chung et al., 1981; Das and Mukherjee, 2004).

In vivo assays

There is still a large amount of uncertainty and discrepancies on the reported in vivo follow up tests. Sasaki et al. (2002) reported the genotoxicity of Amaranth using comet assay on eight mouse organs. Following a 24 $\mathrm{h}$ single dose treatment, amaranth at doses lower than the admissible daily intake (2000 mg/kg-body weight (b.w.)) showed genotoxicity damage in three different organs. There is insufficient evidence to confirm carcinogenicity of Amaranth in humans and it is presently unclassified as a human carcinogen.

Table 1. The most popular synthetic food colours.

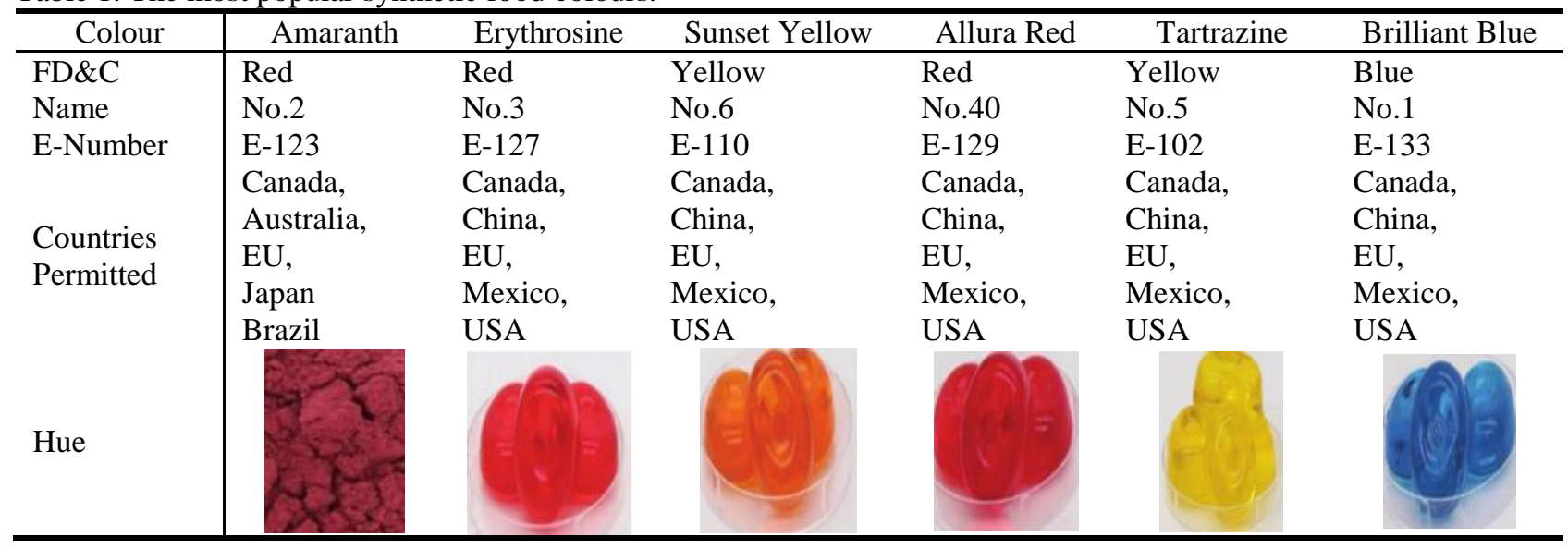

Table 2. Amaranth

\begin{tabular}{|c|c|}
\hline Colour & Amaranth Food Red No.2 \\
\hline Chemical name & Trisodium 2-hydroxy-1-(4-sulphonato-1 naphthylazo)naphthalene-3,6-disulphonate. \\
\hline $\begin{array}{l}\text { Chemical } \\
\text { structure }\end{array}$ & Amaranth $\mathrm{SO}_{3} \mathrm{Na}$ \\
\hline $\begin{array}{l}\text { Physical } \\
\text { description }\end{array}$ & $\begin{array}{l}\text { Amaranth is a monazo dye that is typically reddish brown to dark reddish brown powder or } \\
\text { granules. Amaranth provides a dark red to purple colour in applications and is soluble in water and } \\
\text { sparingly soluble in ethanol. }\end{array}$ \\
\hline Common uses & $\begin{array}{l}\text { Amaranth is used for colouring confectionery products, beverages, desserts, cereals, bakery } \\
\text { products, dairy products, sausages, and snack foods. }\end{array}$ \\
\hline $\begin{array}{l}\text { Consumption } \\
\text { levels }\end{array}$ & $\begin{array}{l}\text { JECFA: ADI of 0-0.5 mg/kg body weight (JECFA, 28th Report, 1984). } \\
\text { USA: Not allowed for use in food, drugs, and cosmetics. } \\
\text { EU: ADI of } 0.15 \mathrm{mg} / \mathrm{kg} \text { body weight (EFSA, 2010); EFSA has also established the maximum } \\
\text { permitted levels (MPLs) for use of Amaranth in foods and beverages in Europe. } \\
\text { Amaranth is also permitted in countries such as Canada, Australia, New Zealand and Brazil where } \\
\text { it can be used in items such as soft drinks, edible ices, preserves, canned foods and confectionery } \\
\text { at ranges of } 30-120 \mathrm{mg} / \mathrm{kg} \text {. }\end{array}$ \\
\hline
\end{tabular}




\section{Tartrazine}

A bright-orange yellow powder freely soluble in water. Hydrochloric acid does not change the aqueous solution while, becomes redder in the presence of sodium hydroxide. The chemical name, chemical structure, common use and ADI of Tartrazine are tabulated in Table 3.

Cytogenetic evaluation

The interaction of Tartrazine and endogenous material like bovine hemoglobin was described as spontaneously involving Van der Waal's forces and hydrogen bonds between the oxygen atoms at position 31 and 15 in the dye (Li et al., 2014). In a similar study, Tartrazine showed extensive DNA binding, cytostatic potential and reduced mitotic index (Mpountoukas et al., 2010).

Gene mutation assays

Several reports have indicated the non-mutagenicity of Tartrazine using Salmonella typhimurium and Escherichia coli (Chung et al., 1981; Das and Mukherjee, 2004; Elhkim et al., 2007; EFSA, 2009a).

In vivo assays

Sasaki et al. (2002) reported the results of comet assay on eight mouse organs following oral administration of Tartrazine up to doses of $2000 \mathrm{mg} / \mathrm{kg}$-b.w. After only $3 \mathrm{~h}$ post-administration, DNA damage was reported at dose levels of $10 \mathrm{mg} / \mathrm{kg}-\mathrm{b} . \mathrm{w}$ in the colon and the glandular stomach at doses higher than $10 \mathrm{mg} / \mathrm{kg}-\mathrm{b} . \mathrm{w}$. (Sasaki et al., 2002). Poul et al., (2009) demonstrated the nonmutagenicity of Tartrazine when administered as oral gavage up to doses of $2000 \mathrm{mg} / \mathrm{kg}-\mathrm{b}$.w.

\section{Allura red}

A red azo dye used as a color in both food and beverages. It is usually supplied as its red $\mathrm{Na}$ salt and can also be used as $\mathrm{Ca}$ or $\mathrm{K}$ salts. These salts are soluble in $\mathrm{H}_{2} \mathrm{O}$. The chemical name, chemical structure, common uses and ADI of Allura red are presented in Table 4.

Cytogenetic evaluation

Allura red is non-genotoxic in many gene mutation tests involving prokaryotic and eukaryotic cells with or without activation (Chung et al., 1981; Combes and Haveland-Smith, 1982; (Kobylewski and Jacobson, 2012). However, Allura red was reported to show direct genotoxic effect when different concentrations of the dye ranging from 9.76 to $5000 \mu \mathrm{g} / \mathrm{ml}$ was incubated with a culture of Saccharomyces cerevisiae at $37^{\circ} \mathrm{C}$. Comet assay revealed dose-related DNA damage starting at concentration of $1250 \mu \mathrm{g} / \mathrm{ml}$, though no positive correlation could be established with exposure time (Jabeen et al., 2013).

In vivo assays

The non-teratogenicity of Allura red has been reported after groups of 11 days old pregnant rats were fed up to $2000 \mathrm{mg} / \mathrm{kg}$-b.w. of single oral doses of Allura red (Tsuda et al., 2001). Comet assay was used to assess DNA damage in the embryo at 3, 6 and $24 \mathrm{~h}$ sampling times. When assessed by comet assay, colon-specific DNA damage was reported in mice at doses of $10 \mathrm{mg} / \mathrm{kg}-\mathrm{b}$.w. three hours post-administration but no damage was observed in rats at any of the tested dye doses or exposure times (Shimada et al., 2010).

Table 3. Tartrazine

\begin{tabular}{|c|c|}
\hline Colour & Tartrazine FD\&C Yellow No. 5, Food Yellow No.4 \\
\hline Chemical name & 3-carboxy-5-hydroxy-1-(4'sulphophenyl)-4-(4'-sulphophenylazo) pyrazoletrisodium salt. \\
\hline $\begin{array}{l}\text { Chemical } \\
\text { structure }\end{array}$ & Tartrazine \\
\hline $\begin{array}{l}\text { Physical } \\
\text { description }\end{array}$ & $\begin{array}{l}\text { Tartrazine is a lemon yellow dye that provides a yellow to orange shade in applications. FD\&C } \\
\text { Yellow } 5 \text { is principally the trisodium salt of 4,5-dihydro-5-oxo-1-(4-sulfophenyl) 4- [4- } \\
\text { sulfophenyl-azo] -1H-pyrazole -3-carboxylic acid. It is soluble in water and sparingly soluble in } \\
\text { ethanol. The chemical name is 5-oxo-1-(p-sulfophenyl)-4- [(p-sulfophenyl) azo]-2-pyrazoline-3- } \\
\text { carboxylic acid, trisodium salt. }\end{array}$ \\
\hline Common uses & $\begin{array}{l}\text { FD\&C Yellow 5, also known as Tartrazine, has been used in foods since } 1916 \text { and provides a } \\
\text { pleasing lemon yellow colour when used in foods, drugs, and cosmetics. It is used to colour } \\
\text { beverages, dessert powders, candy and confections, ice cream, custards, puddings, preserves, } \\
\text { bakery, dairy fats and oil, meat, seafood, snacks, dry mixes and seasonings, fruit preparations, } \\
\text { convenient foods and flavours. }\end{array}$ \\
\hline $\begin{array}{l}\text { Consumption } \\
\text { levels }\end{array}$ & $\begin{array}{l}\text { The FDA established a maximum ADI for FD\&C Yellow No. } 5 \mathrm{of} 5.0 \mathrm{mg} / \mathrm{kg} \text { of body weight per } \\
\text { day (Kobylewski and Jacobson, 2012). This level is equivalent to } 300 \mathrm{mg} \text { (about } 0.01 \mathrm{oz} \text { ) per day } \\
\text { for a } 60 \mathrm{~kg}(132 \mathrm{lb} \text { ) person. EU established a maximum ADI of } 7.5 \mathrm{mg} / \mathrm{kg} \text { of body weight per day, } \\
\text { based on the result of animal studies. This level is equivalent to } 450 \mathrm{mg}(0.016 \mathrm{oz}) \text { per day for a } 60 \\
\mathrm{~kg} \text { person. } \\
\text { USA: GMP (FDA, } 21 \mathrm{CFR} 74.705) \text {, FDA also maintains an ADI of } 5 \mathrm{mg} / \mathrm{kg} \text { bw/day. } \\
\text { EU: ADI of } 0-7.5 \mathrm{mg} / \mathrm{kg} \text { body weight; EFSA has also established MPLs for use of Tartrazine in } \\
\text { foods and beverages in Europe } \\
\text { JECFA: ADI of } 0-10 \mathrm{mg} / \mathrm{kg} \text { body weight (JECFA 82nd Meeting Summary \& Conclusions, 2016). }\end{array}$ \\
\hline
\end{tabular}


Table 4. Allura red

\begin{tabular}{l|l}
\hline \multicolumn{1}{c|}{ Colour } & Allura Red FD \& C Red 40 \\
$\begin{array}{l}\text { Chemical name } \\
\text { structure }\end{array}$ & disodium 2-hydroxy-1-(2-methoxy-5methyl-4-sulphonatophenylazo) naphthalene-6sulphonate. \\
$\begin{array}{l}\text { Physical } \\
\text { description } \\
\text { Common uses }\end{array}$ & $\begin{array}{l}\text { Allura Red is a highly versatile food colour used in dairy fats and oil, snacks, convenient food, } \\
\text { confectionery, dry mixes and seasonings, flavours, gelatin, puddings, custards, alcoholic and non- } \\
\text { alcoholic beverages, fruit preparations, canned and frozen fruit juices, dairy products, bakery } \\
\text { products, sausage casings, jams, jellies, condiments, candy, frostings, meat, poultry and seafood. } \\
\text { FD\&C Red No. 40 is also used in pharmaceuticals and cosmetics (Kobylewski and Jacobson, 2012). } \\
\text { USA: GMP (FDA, 21 CFR 74.340); US FDA also maintains ADI of 7.0 mg/kg-bw day (Kobylewski } \\
\text { Consumption } \\
\text { levels }\end{array}$ \\
$\begin{array}{l}\text { EU: ADI of 0-7 mg/kg body weight (EFSA, 2009b); EFSA has also established MPLs for use of } \\
\text { Allura Red in foods and beverages in Europe. } \\
\text { JECFA: ADI of 0-7 mg/kg body weight (JECFA,25th Report, 1981). } \\
\text { An acceptable daily intake (ADI) of 7 mg/kg body weight per day is equivalent to 420 mg (.015 oz) } \\
\text { per day for a 60 kg (132 lb) person. }\end{array}$
\end{tabular}

Table 5. Sunset yellow

\begin{tabular}{l|l}
\hline \multicolumn{1}{c}{ Colour } & \multicolumn{1}{c}{ Sunset yellow FCF Food Yellow No.6, CAS No. 2783-94-0. } \\
\hline Chemical name & Disodium 6-hydroxy-5-[(4sulfophenyl) azo]-2-naphthalenesulfonate. \\
\hline $\begin{array}{l}\text { Chemical } \\
\text { structure }\end{array}$ & $\begin{array}{l}\text { Sunset Yellow is a yellow dye that provides a reddish-orange shade in applications. FD\&C Yellow } \\
\text { Po. 6 is principally the disodium salt of 6-hydroxy-5-[(4-sulfophenyl)azo]-2- naphthalenesulfonic } \\
\text { acid. The trisodium salt of 3-hydroxy-4[(4-sulfophenyl)azo]-2,7- naphthalenesulfonic acid may be } \\
\text { added in smaller amounts. }\end{array}$ \\
\hline Common uses & $\begin{array}{l}\text { FD\&C Yellow No. 6, also known as Sunset Yellow, has been used in foods since 1929 and provides } \\
\text { a pleasing orange color when used in foods, drugs and cosmetics. FD\&C Yellow No. 6 is used to } \\
\text { color dessert powders, cereals, bakery goods, snack foods, confectioneries, cherries, sausage, ice } \\
\text { cream, sherbet, dairy products, dairy fats and oil, meat, seafood, dry mixes and seasonings, fruit } \\
\text { preparations, convenient food, flavours and beverages (Kobylewski and Jacobson, 2012). }\end{array}$ \\
\hline $\begin{array}{l}\text { USA: maximum ADI of 3.75 mg/kg of body weight per day (Kobylewski and Jacobson, 2012). This } \\
\text { levels }\end{array}$ & $\begin{array}{l}\text { Eevel is equivalent to 225 mg per day for a 60 kg person. } \\
\text { JECFA: ADI of 0-4 mg/kg body weight (JECFA, 74th Report, 2011) }\end{array}$ \\
\hline
\end{tabular}

\section{Sunset yellow $(\mathrm{FCF})$}

Sunset yellow in the form of orange-red crystals is soluble in water. It forms reddish-orange solution in concentrated sulfuric acid, changing to yellow on dilution. Table 5 shows the chemical name, chemical structure, common uses and ADI of Sunset yellow.

Cytogenetic evaluation

Early reports demonstrated the non-mutagenicity of Sunset yellow on E. coli, four tester strains of $S$. typhimurium TA 1538, 1535, 100 and 98 strains with or without metabolic activation (Chung et al., 1981; JECFA, 1982; Wever et al., 1989). Haveland-Smith and Combes (1980), also tested the ability of twenty five dyes to induce mutations in a tryptophan-requiring $E$. coli strain (sensitive to base substitutions) and a histidine auxotroph of $S$. typhimurium strain TA1538 (specific for frame shifts). Sunset yellow was demonstrated to be non-mutagenic with or without metabolic activation.

In vivo assays

Sunset Yellow FCF did not induce DNA damage in any of the eight mouse organs-glandular stomach, colon, liver, kidney, urinary bladder, lung, brain, bone marrowassessed by comet assay following a single oral dosing of the dye up to $2000 \mathrm{mg} / \mathrm{kg}$ (Sasaki et al., 2002; Kobylewski and Jacobson, 2012).

Chronic toxicity

A number of studies describing the administration of Sunset yellow in doses of 0 to $2 \%$ in mice for periods of 52 
to 80 weeks have reported no significant difference in the incidence of tumours when compared with appropriate control groups (Bonser et al., 1956; Gaunt et al., 1974; JECFA, 1982; EFSA, 2009c). Similarly long-term studies in rats, hamster and dogs have not detected any carcinogenic effects associated with the dye when administered up to $5 \%$ doses (JECFA, 1982; EFSA, 2009c).

\section{Erythrosine}

A brown powder. It is soluble in $\mathrm{H}_{2} \mathrm{O}$ and ethanol. It reacts with hydrochloric acid and produces a yellowish brown precipitate. It also reacts with sodium hydroxide and produces a precipitate soluble in access of the reagent. Table 6 presents the chemical name, chemical structure, common uses and ADI of Erythrosine.

Cytogenetic evaluation

A high degree of cytotoxicity and cytostaticity has been reported at Erythrosine doses of 2,4 and $8 \mathrm{mM}$ when tested on human peripheral blood cells in vitro (Mpountoukas et al., 2010). In the same study, extensive direct binding of the dye to calf thymus DNA was reported.

Long-term carcinogenicity

Long term carcinogenicity studies have demonstrated that there was no significant difference in the incidence of non-neoplastic lesions or malignant tumours observed in the control and treated groups of Charles River CD weanling rats of both genders that have been exposed in utero to the dye and subsequently fed Erythrosine doses of $0.1,0.5$, or $1.0 \%$ for 30 months (Borzelleca et al., 1987; EFSA, 2011).

In another study, no tumour was observed in groups of Osborne Mendel rats that received oral gavages $(0,0.5,1.0$, 2.0 or $5.0 \%$ ) or sub-cutaneous injections $(12 \mathrm{mg} / \mathrm{rat})$ for 24 months (Hansen et al., 1973). No mortality or dose-related adverse effects were reported in a similar study where groups of three female and three male beagle dogs were fed $0,0.5,1.0,2.0$ or $5.0 \%$ for 2 years (Hansen et al., 1973).

\section{Gene mutation assays}

The inability of Erythrosine to induce gene mutation in S. typhimurium strains TA 98, TA 100, TA 1535 , TA 1537 and TA 1538 at concentrations of up to $10,000 \mu \mathrm{g} /$ plate have been demonstrated. The dye or its metabolites are reportedly non-mutagenic (Auletta et al., 1977; Bonin and Baker, 1980; Ishidate et al., 1984; JECFA, 1986; EFSA, 2011). In another report, Erythrosine was not only nonmutagenic in S. typhimurium strains TA 97a, TA 98, TA 100, TA 102 and TA 104 but also reduced the antimutagenic potential of benzopyrene, sodium azide and ethidium bromide (Lakdawalla and Netrawali, 1988).

Erythrosine (at doses of 50, 100 and $200 \mathrm{mg} / \mathrm{kg}-\mathrm{b} . \mathrm{w}$. repeated after $24 \mathrm{~h}$ ) did not increase the frequency of sister chromatid exchanges in peripheral blood lymphocytes in male $\mathrm{B} 6 \mathrm{C} 3 \mathrm{~F} 1$ mice. No increase in the frequency of micronuclei in the bone marrow polychromatic erythrocytes or peripheral blood reticulocytes was also observed. The authors suggested that the lack of a clastogenic potential provides support for the nongenotoxic mechanism of the carcinogenicity of Erythrosine (Zuno et al., 1994).

\section{Brilliant Blue (FCF)}

A reddish violet powder or granules with a metallic luster. It is soluble in $\mathrm{H}_{2} \mathrm{O}$ and alcohol. It has pale amber solution in concentrated sulfuric acid, changing to yellow then greenish blue on dilution. The chemical name, chemical structure, common uses and ADI of Brilliant blue are presented in Table 7 .

\section{Table 6. Erythrosine}

\begin{tabular}{|c|c|}
\hline Colour & Erythrosine Food Red No. 3 \\
\hline Chemical name & disodium 2-(2,4,5,7-tetraiodo-6-oxido-3oxoxanthen-9-yl) benzoate. \\
\hline $\begin{array}{l}\text { Chemical } \\
\text { structure }\end{array}$ & Enthrosine \\
\hline $\begin{array}{l}\text { Physical } \\
\text { description }\end{array}$ & $\begin{array}{l}\text { FD\&C Red No. } 3 \text { is principally the monohydrate of } 9 \text { (o-carboxyphenyl)-6-hydroxy2,4,5,7- } \\
\text { tetraiodo-3H-xanthen-3-one, disodium salt, with smaller amounts of lower imidinatedfluoresceins. } \\
\text { Erythrosine is a bluish pink dye that lends a pink shade to applications. }\end{array}$ \\
\hline Common uses & $\begin{array}{l}\text { FD\&C Red No.3, also known as Erythrosine, provides a pleasing watermelon-red color when used } \\
\text { in foods and pharmaceuticals. FD\&C Red No. } 3 \text { is used to color dietary supplements, cherries, } \\
\text { jellies, jams, dessert powders, vegetable products, fish products, condiments, confectionary, dairy } \\
\text { fats and oil, snacks, dry mixes and seasonings, fruit preparations, flavours, sausages, casings, } \\
\text { candies and bakery goods (Kobylewski and Jacobson, 2012). }\end{array}$ \\
\hline $\begin{array}{l}\text { Consumption } \\
\text { levels }\end{array}$ & $\begin{array}{l}\text { Erythrosine is approved for use in many countries, including the US, Canada, EU, India and Japan. } \\
\text { Food companies use only small amounts of the color because of its high tinctorial strength - a little } \\
\text { goes a long way. In addition to increasing costs, too much color would make foods unattractive to } \\
\text { the consumer. } \\
\text { USA: GMP (FDA, } 21 \text { CFR 74.303); US FDA also maintains ADI of } 2.5 \mathrm{mg} / \mathrm{kg} \text { bw/day } \\
\text { (Kobylewski and Jacobson, 2012). } \\
\text { JECFA: ADI of } 0-0.1 \mathrm{mg} / \mathrm{kg} \text { body weight (JECFA, 37th meeting, 1990). } \\
\text { EU: ADI of 0-0.1 mg/kg body weight (EFSA, 2011). Erythrosine is exclusively authorized for use } \\
\text { in cocktail and candied cherries, and Bigarreaux cherries (94/36/EC). }\end{array}$ \\
\hline
\end{tabular}


Table 7. Brilliant Blue

\begin{tabular}{|c|c|}
\hline Colour & Brilliant Blue FCF Food Blue No. 1, FD \& C Blue. No.1 \\
\hline Chemical name & $\begin{array}{l}\text { Ethyl - [4 - [ [4 - [ethyl -[(3 - sulfophenyl }) \text { methyl }] \text { amino }] \text { phenyl }]-(2 \text { - sulfophenyl }) \\
\text { methylidene }]-1 \text { - cyclohexa - } 2,5 \text { - dienylidene }]-[(3 \text { - sulfophenyl }) \text { methyl }] \text { azanium. }\end{array}$ \\
\hline Chemical structure & \\
\hline Physical description & $\begin{array}{l}\text { FD\&C Blue No. } 1 \text { is a greenish blue dye that adds a blue shade in applications. Brilliant Blue } \\
\text { FCF is soluble in water and slightly soluble in ethanol. }\end{array}$ \\
\hline Common uses & $\begin{array}{l}\text { It has been used in foods in the US since 1929. This color adds a distinctive, bright blue hue } \\
\text { to beverages, beverage powders, dairy products, baked goods, dessert powders, confections, } \\
\text { condiments, icings, syrups, jams, jellies, marmalades, liqueurs, extracts, dairy fats and oil, } \\
\text { meat, seafood, snacks, dry mixes and seasonings, fruit preparations, convenient food, and } \\
\text { flavors (Kobylewski and Jacobson, 2012). }\end{array}$ \\
\hline Consumption levels & $\begin{array}{l}\text { Brilliant Blue is approved for use in many countries throughout the world, including the US, } \\
\text { Canada, India, Japan and the European Union. } \\
\text { USA: GMP (FDA, } 21 \text { CFR 74.101); US FDA also maintains ADI of } 12.0 \mathrm{mg} / \mathrm{kg} \text {-bw day } \\
\text { (Kobylewski and Jacobson, 2012). } \\
\text { EU: ADI of } 0-6 \mathrm{mg} / \mathrm{kg} \text { body weight (EFSA, 2010); EFSA has also established MPLs for use } \\
\text { of Brilliant Blue in foods and beverages in Europe } \\
\text { JECFA: ADI of 0-12.5 mg/kg-body weight (JECFA, 13th Report; } 1969) \\
\text { JECFA's maximum ADI is equivalent to } 750 \mathrm{mg} \text { (about .02 oz) per day for a } 60 \mathrm{~kg}(132 \mathrm{lb} \text { ) person. }\end{array}$ \\
\hline
\end{tabular}

\section{In vivo assays}

Brilliant Blue did not increase the frequency of micronuclei in the bone marrow of groups of mice that received intra-peritoneal doses of $0,500,1000$ or 2000 $\mathrm{mg} / \mathrm{kg}$-bw (EFSA, 2010). In another study that was not considered by the last EFSA re-evaluation of brilliant blue because of the inconsistent osmolality of cell culture medium used, the dye was reportedly genotoxic in the chromosome aberration assay of over 190 additives using Chinese hamster fibroblast cell line (Ishidate et al., 1984; EFSA, 2010). The colourant at doses up to $2000 \mathrm{mg} / \mathrm{kg}$ b.w. gave negative results in a genotoxicity assessment of 39 food additives by comet assay on eight mouse organs (Sasaki et al., 2002).

\section{Long-term carcinogenicity}

In a lifetime/carcinogenicity study that involve $\mathrm{F} 0$ and $\mathrm{F} 1$ generation, dye doses of $0,0.1,1.0$ or $2.0 \%$ were fed to groups of Charles River CD rats for a period of 116 weeks for the males and 111 weeks for the females. A noobserved-adverse-effect-level (NOAEL) of 2 and 1\% was established for the male and female groups respectively. In the same study with CD mice fed up to $5 \%$ dye, no adverse effects was observed and the NOAEL was established at $5 \%$ for both genders (Borzelleca et al., 1990).

In a study conducted before the OECD guidelines were formulated and publicized, dietary concentrations of brilliant Blue, $0.03,0.3$ or $3 \%$ when fed to groups of 30 rats for 75 weeks did not produce any dose-related adverse effects on the growth or mortality (Mannell et al., 1962). Similar results were seen with the sub-cutaneous injection (Mannell and Grice, 1964).

Gene mutation assays

The non-mutagenicity of brilliant blue in various Salmonella strains with or without metabolic activation has been demonstrated in many studies (Brown et al., 1978; Bonin and Baker, 1980; Haveland-Smith and Combes, 1980; Ishidate et al., 1984).

\section{Conclusion}

It could be concluded that the present review indicated that synthetic colorants are adversely affecting hepatic and renal parameters comparing to natural colorants. Therefore, it is necessary be aware about the hazardous effects of consuming such synthetic food colorants. Furthermore, the implementation of laws, regulations, proper labelling and awareness programs of artificial food dyes for customers and food processors are highly recommended looking for food safety. Also, further research is needed to evaluate toxicity of synthetic food colors.

\section{Conflict of Interest}

The authors have declared no conflict of interest.

\section{References}

Asif Ahmed M, Al-Khalifa AS, Al-Nouri DM, Serag El-din MF. 2021. Dietary intake of artificial food color additives containing food products by school-going children. Saudi Journal of Biological Sciences 28 (2021) 27-34. https://doi.org/10.1016/j.sjbs.2020.08.025

Auletta AE, Kuzava JM, Parmar AS. 1977. Lack of mutagenic activity of a series of food dyes for Salmonella typhimurium. Mutat. Res. 56:203.

Bonin AM, Baker RS 1980. Mutagenicity testing of some approved food additives with Salmonella microsome assay. Food Technol. Aust. 32(12):608-611.

Bonser GM, Clayson DB, Jull JW. 1956. The induction of tumours of the subcutaneous tissues, liver and intestine in the mouse by certain dyestuffs and their intermediates. Br. J. Cancer 10(4):653-667.

Borzelleca JF, Capen CC, Hallagan JB. 1987. Lifetime toxicity/carcinogenicity study of FD \& C Red No. 3 (erythrosine) in rats. Food Chem. Toxicol. 25(10):723-733. 
Borzelleca JF, Depukat K, Hallagan JB. 1990. Lifetime toxicity/carcinogenicity studies of FD \& C Blue No. 1 (brilliant blue FCF) in rats and mice. Food Chem. Toxicol, 28(4):221-234.

Brown JP, Roehm GW, Brown RJ. 1978. Mutagenicity testing of certified food colors and related azo, xanthene and triphenylmethane dyes with the Salmonella/microsome system. Mutat. Res. 56(3):249-271.

Chung KT, Fulk G, Andrews A. 1981. Mutagenicity testing of some commonly used dyes. Appl. Environ. Microbiol. 42(4):641-648.

Clydesdale FM. 1993. Color as a factor in food choice. Critical Reviews in Food Science and Nutrition 33, 83-101.

Combes RD, Haveland-Smith RB. 1982. A review of the genotoxicity of food, drug and cosmetic colours and other azo, triphenylmethane and xanthene dyes. Mutat. Res. 98(2):101-243.

Das A, Mukherjee A. 2004. Genotoxicity testing of food colours amaranth and tartrazine. Int. J. Hum. Gen. 4:277-280. https://doi.org/10.1080/09723757.2004.11885906

EFSA 2009a. EFSA Panel on Food Additives and Nutrient Sources added to Food; Scientific Opinion on the reevaluation of Tartrazine (E 102) as a food additive. EFSA 7:1331-1383. DOI: https://doi.org/10.2903/j.efsa.2009.1331

EFSA 2009b. EFSA Panel on Food Additives and Nutrient Sources added to Food: Scientific Opinion on the reevaluation of Allura Red AC (E 129) as a food additive. EFSA 7(11):1327-1366. DOI: https://doi.org/10.2903/ j.efsa.2009.1327

EFSA 2009c. EFSA Panel on Food Additives and Nutrient Sources added to Food (ANS): Scientific Opinion on the re-evaluation of Sunset Yellow FCF (E 110) as a food additive. EFSA 7(11):13301374. DOI:https://doi.org/10.2903/j.efsa.2009.1330

EFSA 2010. EFSA Panel on Food Additives and Nutrient Sources added to Food: Scientific Opinion on the re-evaluation of Brilliant Blue FCF (E 133) as a food additive. EFSA 8(11):1853-1889. DOI: https://doi.org/10.2903/j.efsa. 2010.1853

EFSA 2011. EFSA Panel on Food Additives and Nutrient Sources added to Food; Scientific Opinion on the re-evaluation of Erythrosine (E 127) as a food additive. EFSA 9(1):18541900. DOI: https://doi.org/10.2903/j.efsa.2011.1854

EFSA 2012. Scientific Opinion on the safety and efficacy of Allura Red AC (E 129) in feed for cats and dogs. EFSA 10(5):2675-2689. DOI: https://doi.org/10.2903/j.efsa. 2012.2675

EFSA 2013. EFSA Panel on Food Additives and Nutrient Sources added to Food; Scientific Opinion on the re-evaluation of aspartame (E 951) as a food additive. EFSA 11(12):34963759. DOI: https://doi.org/10.2903/j.efsa.2013.3496

Elhkim M.O., Heraud F., Bemrah N., Gauchard F., Lorino T., Lambre C. and Poul J.M. 2007. New considerations regarding the risk assessment on Tartrazine An update toxicological assessment, intolerance reactions and maximum theoretical daily intake in France. Regul. Toxicol. Pharmacol. 47(3):308316. DOI: $10.1016 / j . y r t p h .2006 .11 .004$

FDA 2018. Color Additives. Available at: https://www.fda.gov /industry/color-additives.

Gaunt IF, Mason PL, Grasso P, Kiss IS. 1974. Long-term toxicity of Sunset Yellow FCF in mice. Food Cosmet. Toxicol. 12(1):1-9.

Hansen WH, Zwickey RE, Brouwer JB, Fitzhugh OG. 1973. Long-term toxicity studies of erythrosine. I. Effects in rats and dogs. Food Cosmet. Toxicol. 11(4):527-534.

Haveland-Smith RB, Combes RD. 1980. Screening of food dyes for genotoxic activity. Food Cosmet. Toxicol. 18(3):215-221.

Ishidate Jr. M, Sofuni T, Yoshikawa K, Hayashi M, Nohmi T, Sawada M. and Matsuoka A. 1984. Primary mutagenicity screening of food additives currently used in Japan. Food Chem. Toxicol. 22(8):623-636.
Jabeen HS, ur Rahman S, Mahmood S, Anwer S. 2013. Genotoxicity assessment of amaranth and allura red using Saccharomyces cerevisiae. Bull. Environ. Contam. Toxicol. 90(1):22-26. PMID: 23132362 DOI: 10.1007/s00128-012-0870-x

Jadhav RV, Bhujbal SS. 2020. A review on natural food colors. Pharmaceutical Resonance, 2 (2):12-20.

JECFA 1969. Toxicological evaluation of some food colors, emulsifiers, stabilizers, anticaking agents and certain other substances. FAO Nutrition Meetings Reports Series No. 46A.

JECFA 1981. Evaluation of certain food additives (Twenty-fifth report of the Joint FAO/WHO Expert Committee on Food Additives). WHO Technical Report Series, No. 669,1981.

JECFA 1982. Specifications for identity and purity of buffering agents, salts, emulsifiers, thickening agents, stabilizers, flavouring agents, food colors, sweetening agents and miscellaneous food additives.

JECFA 1984. Evaluation of certain food additives and contaminants (Twenty-eighth report of the Joint FAO/WHO Expert Committee on Food Additives). WHO Technical Report Series, No. 710, 1984, and corrigendum.

JECFA 1986. Toxicological evaluation of certain food additives and contaminants. 30th Report. WHO Food Additives Series.

JECFA 1990. Specifications for identity and purity of certain food additives. $37^{\text {th }}$ meeting.

JECFA 2011. Evaluation of certain food additives and contaminants (Seventy-fourth report of the Joint FAO/WHO Expert Committee on Food Additives). WHO Technical Report Series, No. 966. https://apps.who.int/iris/handle/ $10665 / 44788$

JECFA 2016. Evaluation of certain food additives (Eighty-second report of the Joint FAO/WHO Expert Committee on Food Additives) WHO Technical Report Series, No.1000. https://apps.who.int/iris/handle/10665/250277

Kobylewski S, Jacobson MF. 2012. Review: Toxicology of food dyes. International Journal of Occupational and Environmental Health, 18 (3):220-246. https://doi.org/10.1179/ 1077352512Z. 00000000034

Lakdawalla AA, Netrawali MS. 1988a. Mutagenicity, comutagenicity, and antimutagenicity of erythrosine (FD and C red 3), a food dye, in the Ames/Salmonella assay. Mutat. Res. 204(2):131-139.

Lakdawalla AA, Netrawali MS. 1988b. Erythrosine, a permitted food dye, is mutagenic in the Bacillus subtilis multigene sporulation assay. Mutat. Res. 206(2):171-176.

Li Y, Wei H, Liu R. 2014. A probe to study the toxic interaction of tartrazine with bovine hemoglobin at the molecular level. Luminescence 29(2):195-200. PMID: 23653408 DOI: 10.1002/bio. 2510

Mannell WA, Grice HC. 1964. Chronic toxicity of brilliant blue FCF, blue VRS, and green S in rats. J. Pharm. Pharmacol. 16(1):56-59.

Mannell WA, Grice HC, Allmark MG. 1962. Chronic Toxicity Studies on Food Colours: V. Observations on the Toxicity of Brilliant Blue FCF, Guinea Green B and Benzyl Violet 4B in Rats. J. Pharm. Pharmacol. 14(1):378-384.

Maronpot RR, Hayashi S, Bastaki M. 2020. Synthetic and natural food colorants. Foods \& Food Ingredients J. JPN,. 225 (2):100-110.

Meggos H. 1995. Food colours: an international perspective. Manufacturing Confectioner 1995: 59-65.

Mpountoukas P, Pantazaki A, Kostareli E, Christodoulou P, Kareli D, Poliliou S, Lialiaris T. 2010. Cytogenetic evaluation and DNA interaction studies of the food colorants amaranth, erythrosine and tartrazine. Food Chem. Toxicol. 48(10): 2934-2944. PMID: 20667460. DOI: 10.1016/ j.fct.2010.07.030

Poul M, Jarry G, Elhkim MO, Poul JM. 2009. Lack of genotoxic effect of food dyes amaranth, sunset yellow and tartrazine and their metabolites in the gut micronucleus assay in mice. Food Chem. Toxicol. 47(2): 443-448. doi: 10.1016/j.fct.2008.11.034. Epub 2008 Dec 6. 
Sasaki YF, Sekihash Kl, Zumiyama F, Nishidate E, Saga A, Ishida K, Tsuda S. 2000. The Comet Assay with Multiple Mouse Organs: Comparison of Comet Assay Results and Carcinogenicity with 208 Chemicals selected from the IARC Monographs and U.S. NTP Carcinogenicity Database. Crit. Rev. Toxicol. 30(6): 629-799. PMID: 11145306. DOI: 10.1080/10408440008951123

Sasaki YF, Kawaguchi S, Kamaya A, Ohshita M, Kabasawa K, Iwama K, Taniguchi K, Tsuda S. 2002.The comet assay with 8 mouse organs: Results with 39 currently used food additives. Mutation Research/Fundamental and Molecular Mechanisms of Mutagenesis 519(1-2): 103-119. https://doi.org/10.1016/S1383-5718(02)00128-6

Shimada C, Kano K, Sasaki YF, Sato I, Tsuda S. 2010. Differential colon DNA damage induced by azo food additives between rats and mice. J. Toxicol. Sci. 35(4):547554. PMID: 20686341. DOI: 10.2131/jts.35.547
Thomas OE, Adegoke OA. 2015. Toxicity of food colours and additives: A review. African Journal of Pharmacy and Pharmacology, 9(36): 900-914. DOI: 10.5897/AJPP2015.4385

Tsuda S, Murakami M, Matsusaka N, Kano K, Taniguchi K, Sasaki YF. 2001. DNA Damage Induced by Red Food Dyes Orally Administered to Pregnant and Male Mice. Toxicol. Sci.61(1): 9299. PMID: 11294979. DOI: 10.1093/toxsci/61.1.92

Wever J, Munzner R, Renner HW. 1989. Testing of sunset yellow and orange II for genotoxicity in different laboratory animal species. Environ. Mol. Mutagen. 13(3):271-276.

Zuno A, Marcon F, Leopardi P, Salvatore G, Carere A, Crebelli R. 1994. An assessment of the in vivo clastogenicity of erythrosine. Food Chem. Toxicol. 32(2):159-163. 